\title{
Episodic river flooding events revealed by palynological assemblages in Jurassic deposits of the Brent Group, North Sea
}

\author{
Sam M. Slater ${ }^{\mathrm{a}, \mathrm{c}, *}$, Tom McKie $^{\mathrm{b}}$, Manuel Vieira ${ }^{\mathrm{b}}$, Charles H. Wellman ${ }^{\mathrm{a}}$, Vivi Vajda ${ }^{\mathrm{c}}$ \\ a Department of Animal and Plant Sciences, University of Sheffield, Alfred Denny Building, Western Bank, Sheffield S10 2TN, UK \\ b Shell UK Ltd., 1 Altens Farm Road, Nigg, Aberdeen AB12 3FY, UK \\ c Department of Palaeobiology, Swedish Museum of Natural History, SE-104 05 Stockholm, Sweden
}

\section{A R T I C L E I N F O}

\section{Article history:}

Received 17 February 2017

Received in revised form 22 June 2017

Accepted 23 June 2017

Available online 27 June 2017

\section{Keywords:}

Hyperpycnite

Spores and pollen

Rannoch Formation

Palynofacies

Non-metric multidimensional scaling (NMDS)

Botryococcus spp.

\begin{abstract}
A B S T R A C T
Spore and pollen (sporomorph) assemblages from Middle Jurassic marine deposits of the Brent Group in the northern North Sea are investigated to assess temporal and spatial variations in vegetation and depositional processes. Four wells were sampled for palynology from the Penguins Cluster and the Don North East fields through the Rannoch Formation shoreface succession. Hyperpycnite deposits occur throughout, but are concentrated within the lower part of the section. These are expressed by sand-prone beds displaying waxing and waning current motifs, normally graded muddy beds and structureless mudstones. Hyperpycnal/hypopycnal deposits resulting from episodic river flooding represent important sedimentary features as they may be preserved below fair weather wave base in more offshore settings and potentially be the only record of the former presence of a nearby river mouth. The hyperpycnites typically contain abundant Botryoccocus spp., Amorphous Organic Matter (AOM) and hinterland sporomorph taxa with relatively few marine components compared to associated marine shoreface facies. Variations in palynofacies assemblages and Botryococcus spp. abundances indicate frequent river mouth avulsion. Ordination of samples using non-metric multidimensional scaling (NMDS) indicates that shoreface samples of the sampled wells are relatively distinct, but hyperpycnite samples are highly similar regardless of their sampled well. This suggests that depositional processes and spore/pollen sources (i.e. catchment zones) were similar among hyperpycnite events across different wells. Abundant bisaccate pollen, Botryococcus spp. and AOM within interpreted hyperpycnites suggest sediment mixing along the fluvial drainage path during flooding events. The terrestrial signature of hyperpycnite sporomorph assemblages demonstrates that underflows remained coherent as they descended the shoreface profile with little turbulent mixing with ambient marine waters. Sporomorph assemblages display few large changes through time suggesting vegetation on the adjacent coastal plain was relatively static through the studied interval.
\end{abstract}

(C) 2017 Elsevier B.V. All rights reserved.

\section{Introduction}

Hyperpycnite deposits are increasingly recognised in the shallow marine stratigraphic record (Mulder et al., 2003; Zavala et al., 2011). Such deposits provide insights into the processes that operated on ancient shorelines, in many cases providing clues to the former presence of transient river mouths whose shallow water facies have been entirely removed by wave and tidal action. Hyperpycnal flows are negatively buoyant flows that flow along the basin floor due to their higher density, as a result of their particle load compared to the ambient density of the standing water-body (Bates, 1953; Mulder and Syvitski, 1995; Mulder et al., 2003). They form at river mouths during flooding events and can transport substantial volumes of sediment into marine basins (Mulder et al., 2003). Recognition criteria for such deposits are largely

\footnotetext{
* Corresponding author.

E-mail address: sam.slater@nrm.se (S.M. Slater).
}

based on primary depositional structures indicative of waxing and waning flows (cf. Mulder et al., 2001), although the presence of abundant terrigenous organic matter has also been cited as a diagnostic feature (Zavala et al., 2012). These deposits differ from gravity flows resulting from episodic sediment failure in that they record the fluctuating currents associated with flood events. This contrasts with isolated waning flows resulting from sediment failure episodes. Their differentiation can be important to distinguish between deltaic systems dominated by sediment-laden seasonal flow and those capable of building unstable, failure-prone mouth-bars and delta-fronts, or subject to seismic induced failure. Here we identify the products of river flood events based on sedimentological evidence and subsequently investigate their palynomorph content to provide possible further recognition criteria for these deposits. The study area, located in the Penguins Cluster and the Don North East fields (Fig. 1) occupies the northern limit of the Middle Jurassic Brent Delta of the North Sea Viking Graben; a location which has previously been identified as turbidite-prone (Cannon et al., 1992). 

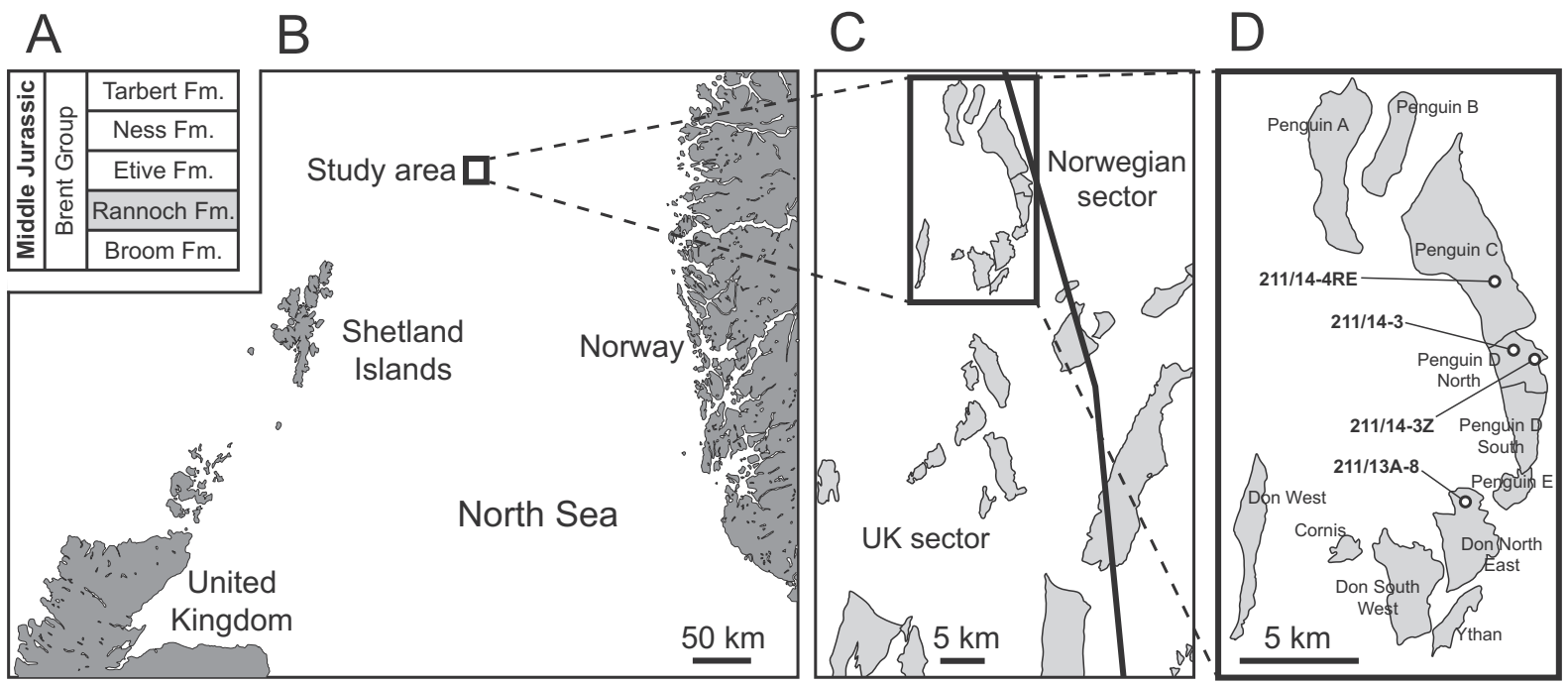

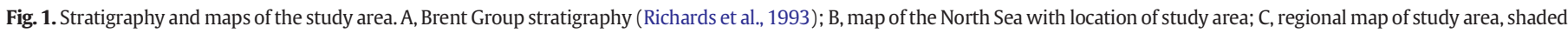
regions represent oil/gas fields; $\mathrm{D}$, well locations, shaded regions represent oil/gas fields.

We also link sporomorphs (spores and pollen) with botanical groups based on studies of spores/pollen preserved in situ within plant reproductive structures (e.g. Balme, 1995) to assess temporal and spatial variations in vegetation and sediment provenance.

\section{Geological setting}

The stratigraphy of the Middle Jurassic Brent Group (Fig. 1A) is largely based on fields in the East Shetland Basin (e.g. Deegan and Scull, 1977; Budding and Inglin, 1981; Cannon et al., 1992; Richards et al., 1993). The Brent Group comprises five formations (Fig. 1A): the Broom, Rannoch, Etive, Ness and Tarbert formations. The basal Broom Formation records lowstand shallow marine sedimentation, with the overlying Rannoch, Etive and Ness formations recording the progradation of an axial, basin-filling, wave-dominated delta under long-term, albeit punctuated, forced regression (Olsen and Steel, 2000; Mjøs, 2009; Went et al., 2013). In addition, Wei et al. (2016) identified a tidal signature within the Rannoch Formation c. $50 \mathrm{~km}$ to the south-east of the Penguin Cluster in the axial part of the basin, suggesting that the Brent delta was more tidally influenced than previously thought. The uppermost Tarbert Formation records subsequent transgression (cf. Hampson et al., 2004). The study area (Fig. 1B-D) (Domínguez, 2007), lies close to the northern limit of delta progradation (cf. Brown and Richards, 1989; Mitchener et al., 1992) and differs from the type section seen to the south-west in the Brent Field. Here the section largely lacks coastal plain Ness Formation facies (Fig. 2) and is dominated by Rannoch lower shoreface and Etive upper shoreface, inlet and beachface sandstones (Scott, 1992; Jackson et al., 2010). Ness-like facies are locally recorded in the greater Penguins area, but are poorly developed and are largely expressed by a relatively thin succession of lagoonal shales or thin coals which lack the facies

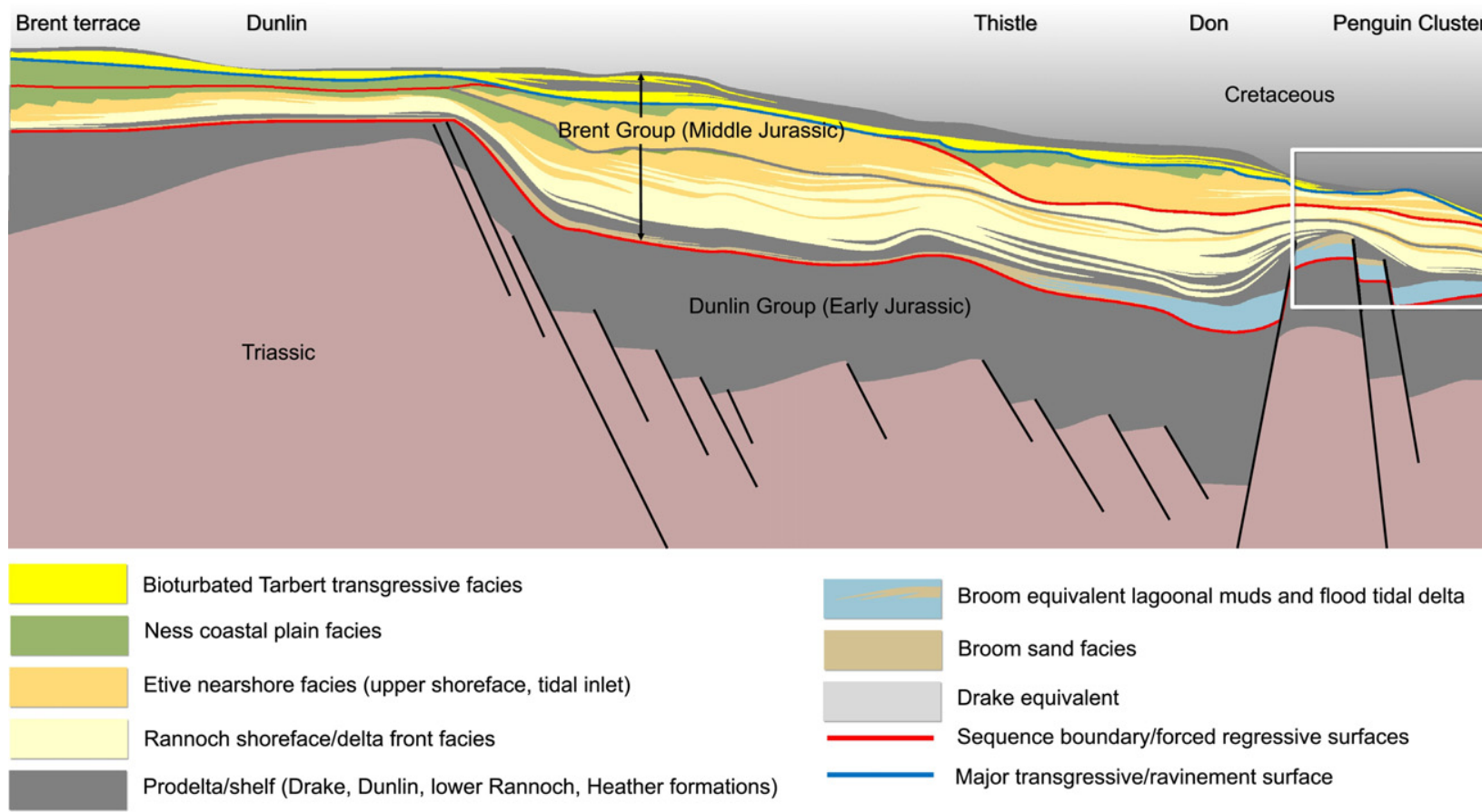

Fig. 2. Schematic facies architecture of the Brent Group extending from the area of the Brent Field north-eastwards to the area of the Penguins Cluster. 
diversity seen to the south (cf. Livera, 1989). Biostratigraphic data indicate that the Rannoch-Etive section in the Penguins Cluster area is the approximate chronostratigraphic equivalent of the Ness Formation in the Brent Field c. $40 \mathrm{~km}$ to the south.

Overall the depositional setting of the Rannoch-Etive section can be compared to modern wave-dominated deltas characterised by a relatively low and/or episodic sediment supply and high degree of wave dispersal (Budding and Inglin, 1981). In these settings the fluvial sediment supply to the coast is largely reworked by wave processes (e.g. Domínguez, 1996; Bhattacharaya and Giosan, 2003) and in extreme cases no mouth bar facies are preserved. Instead, swash bar complexes, analogous to those seen in ebb tidal deltas (Oertel, 1972; Hayes, 1980) reflect the products of mouth bar material reworked between flood events. Following fluvial avulsion deltaic promontories generated by fluvial sediment supply are re-graded to an equilibrium profile adjusted to the ambient wave climate (Bhattacharaya and Giosan, 2003). Distributary channels, deflected by longshore sediment transport by waves into a shore parallel orientation, are also prone to reworking by minor shoreline oscillations. Despite the poor preservation potential of mouth bar and distributary channel facies, hyperpycnal/hypopycnal deposits resulting from episodic river flooding may be preserved below fair weather wave base in more offshore settings and may potentially be the only record of the former presence of a nearby river mouth.

In this paper we examine the sedimentology and palynological signature of the lower portion of the Rannoch Formation in order to investigate the processes that operated in the shallow marine environments distal to the Brent Delta.

\subsection{Rannoch facies}

The overall facies architecture of the Rannoch and Etive section in the Penguins Cluster is broadly comparable to the type area to the south, albeit of a slightly younger age. This study focusses on the lower shoreface Rannoch section where evidence of hyperpycnal deposits is preserved. The section is typically $30-60 \mathrm{~m}$ thick and coarsens-upwards from mudrocks to fine-medium grained sandstones.

\subsubsection{Shoreface facies}

Bioturbated siltstones and sandstones occur in the basal few meters of the Rannoch section and typically possess a diverse trace fossil assemblage (Fig. 3A) dominated by Phycosiphon, Teichichnus, Zoophycos, Terebellina and Cylindrichnus. Primary depositional structures are largely absent and belemnite fragments are locally present. These diversely bioturbated, fossiliferous deposits record low energy, open marine deposition following transgressive drowning of the underlying Broom lagoonal system. The sharp boundary with the underlying Broom Formation, and presence of reworked sandstone and mudstone clasts, indicate that the contact likely represents an erosional ravinement surface. This mud-prone interval as a whole records maximum flooding prior to the rapid reversion to normal and subsequent forced regression (Went et al., 2013).

Stratified and burrowed sandstones dominate the Rannoch succession in the study area, and are characterised by successions of generally clean, fine grained sandstones showing a variety of internal fabrics (Fig. 3B-D). Wave formed structures are common, ranging from small scale,
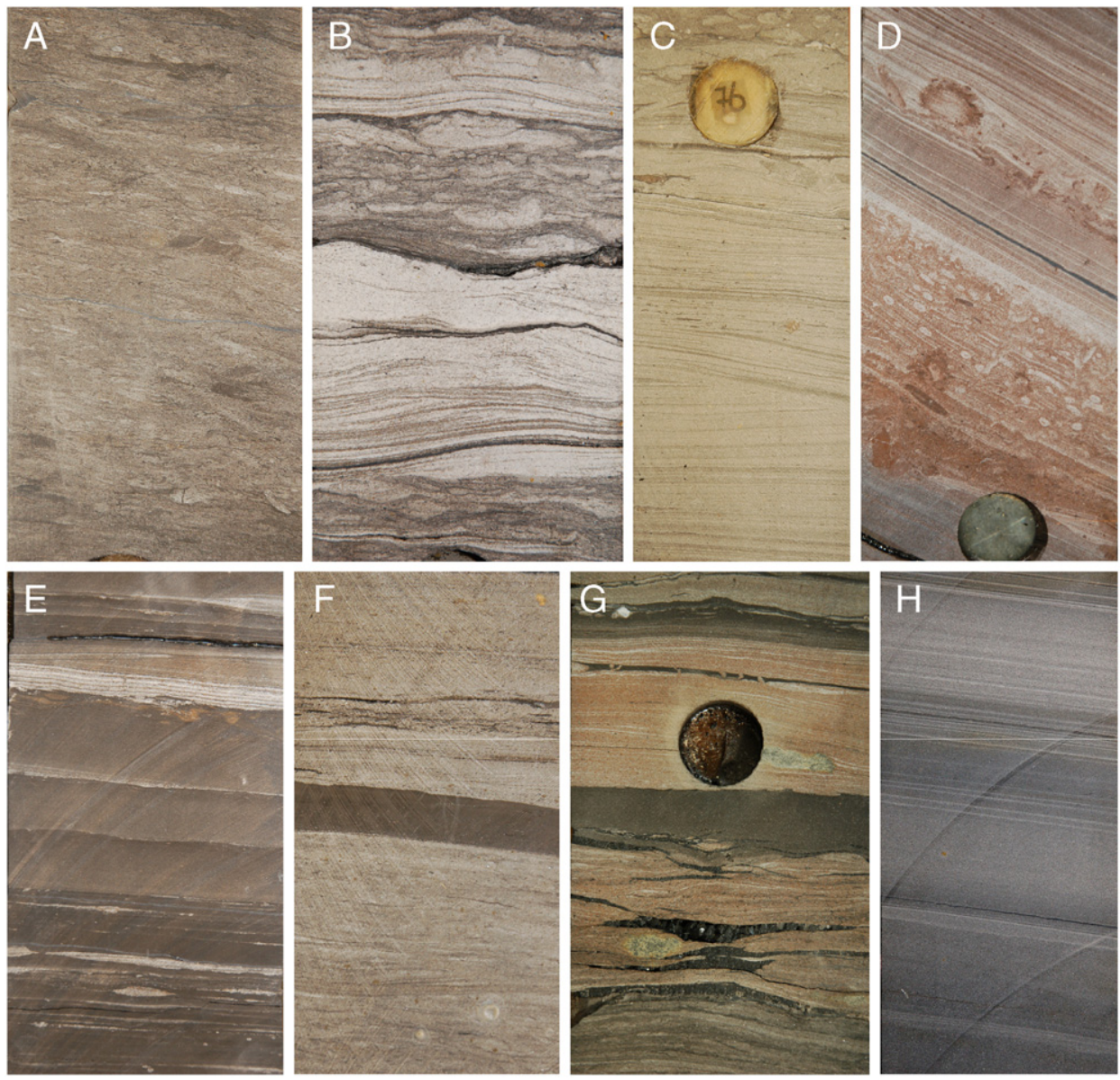

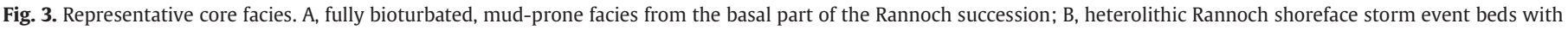

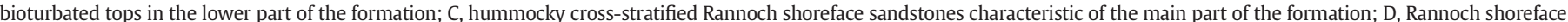

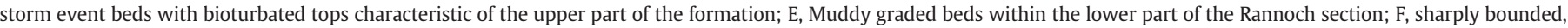

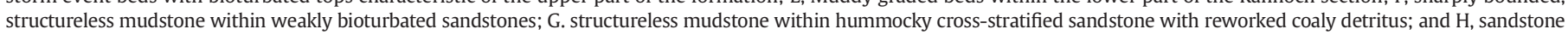
interval showing fluctuations between structureless, weakly stratified and planar laminated fabrics. Core sections are $10 \mathrm{~cm}$ wide. 
combined flow ripples to hummocky cross stratified sandstones with wavelengths visible over the width the of core (Fig. 3B), to large scale hummocks identifiable through antiformal lamination and internal angular truncations (Fig. 3C; cf. Richards and Brown, 1986). Discrete bioturbated colonisation surfaces are locally present (Fig. 3D), containing trace fossils such as Diplocraterion, Macaronichnus, Palaeophycus and Schaubcylindrichnus. Escape burrows are sporadically distributed. However, in many cases large sections of the Rannoch are characterised by clean, apparently structureless sandstones with an indistinct lamination defined by local mica concentrations. On close inspection, these apparently structureless sandstones can be seen to have a pervasive bioturbation fabric dominated by Macaronichnus, or by indistinct cryptobioturbation (cf. Pemberton et al., 2008) which becomes locally better defined where micaceous material is concentrated.

The hummocky cross-stratified beds record episodic deposition under long period waves and combined flows (Southard et al., 1990; Duke et al., 1991; Cheel and Leckie, 1993) on the Rannoch shoreface. Lower in the succession depositional events were sufficiently infrequent to allow the preservation of bioturbated bed tops, but higher in the Rannoch section the uniformly stratified intervals lacking colonisation surfaces are likely to be erosively amalgamated. In the case of the apparently structureless, but intensely bioturbated sandstones it is likely that a large proportion have been overprinted by Macaronichnus. This may be indicative of relatively shallow shoreface deposition (Clifton and Thompson, 1978), and would suggest that some shoreface sections were subject to intense infaunal burrowing during fair-weather periods rather than continuous sediment transport, possibly indicating episodic sheltering from wave action (e.g. on the downdrift margins of river mouths or spits).

\subsubsection{Fluvial flood deposits}

These deposits are sporadically distributed throughout the Rannoch section, commonly occurring as single beds within the background shoreface facies, but locally comprising stacked beds forming intervals of up to a few metres thick.

2.1.2.1. Muddy graded beds. These range in grain size from mudstone to siltstone and rarely to very fine grained sandstone. Muddy graded beds tend to be preserved in the lower parts of the Rannoch section, locally dominating the interval, or interbedded with bioturbated deposits in discrete packages up to a few metres thick. They are characterised by rhythmic stacking of centimetre-scale, normally graded beds which commonly lack any internal fabric, or locally show limited evidence of a planar lamination (Fig. 3E).

These packages could represent: (i) distal, deep water and low energy storm beds deposited below wave base; (ii) storm resuspension of lower shoreface/shelf muds which settled below wave base (Myrow et al., 2002); or (iii) wave enhanced shelf gravity flows (Macquaker et al., 2010). However, their occurrence in discrete packages, general absence of wave formed structures (whilst associated with sediments showing evidence of wave activity) and paucity of biogenic structures (whilst enclosed in bioturbated deposits) suggest that they are the product of dilute turbidity currents which were temporarily focussed into discrete areas of the Rannoch shoreface/delta-front. The sediment load within these packages could have been deposited from decelerating hypopycnal plumes, or bottom-hugging hyperpycnal flows to generate normally graded beds that lack internal fabric. Their discrete packaging within otherwise wave-dominated shoreface facies may therefore reflect the temporary presence of avulsive river mouths which discharged onto the more typically wave-swept Rannoch shoreface.

2.1.2.2. Structureless mudstones. These beds punctuate the entire Rannoch succession, but are particularly common in the lower part of the section. They occur as discrete $\mathrm{cm}$-scale beds characterised by sharp bases and tops, generally lack a fine scale lamination or bioturbation, and are either structureless or very crudely laminated (Figs 3F and G). The beds are typically flat lying, but also locally drape as antiformal wave ripple forms. They punctuate the background Rannoch stratigraphy and do not delineate the boundary between facies.

These muds are comparable to the deposits of fluid mud layers identified by Ichaso and Dalrymple (2009), and may be the product of deposition from high density, bottom-hugging flows (cf. Traykovski et al., 2000). The origin of these is enigmatic. The absence of significant tidal indicators in the Brent succession in this area suggests they are not the product of tidal resuspension, and their rare expression and draping wave formed structures may indicate post-storm deposition of fluid muds. They appear to be entirely terrestrially derived, but lack the coarser grained fraction and grading that might be expected of suspended sediment deposition from discharging rivers. Instead these deposits may be the product of remobilisation of water saturated muds from coastal plain repositories (such as lakes, lagoons or mudfilled channels) by flooding rivers which transported these dense suspensions onto the Rannoch shoreface.

2.1.2.3. Rhythmic sandstones. These beds are characterised by metrescale packages of fine-grained sandstone which display a repetitive alternation between current ripple and planar laminated, or laminated and structureless, sandstone (Fig. $3 \mathrm{H}$ ). They occur in a similar context to the muddy graded beds within otherwise burrowed and wave reworked lower Rannoch deposits.

These sandstones record deposition under fluctuating or surging currents which bear many similarities to sandy hyperpycnites (cf. Mulder et al., 2003; Bhattacharaya and Maceachern, 2009). They are unlikely to represent turbidites resulting from sediment failure, which tend to show structures indicative solely of deceleration (e.g. vertical deceasing grain size (Sumner et al., 2008)), or storm beds, which typically show wave formed structures and tend not to achieve the suspended sediment concentrations that lead to structureless sandstones (e.g. Richards and Brown, 1986). They are instead interpreted as the product of higher energy river mouth flooding than the muddy deposits, and again their occurrence in discrete packages may reflect the temporary presence of an active river mouth on the Rannoch shoreface.

Overall the Rannoch section in the Penguins area shows a dominance of wave processes and no direct evidence of fluvial processes except for the presence of deposits that could be ascribed to river mouth plumes. If these deposits were indeed the product of river mouth processes then a critical test of this would be to examine their palynological composition for evidence of their terrigenous content and how this might contrast with the more open marine facies.

\section{Material and methods}

\subsection{Collection, processing and counting}

Thirty samples were collected from four wells: 211/13A-8, 211/143Z, 211/14-3 and 211/14-4RE through the Rannoch Formation of the Penguins Cluster and the Don North East field, northern North Sea (Fig. 1). Sampling focussed on structureless mudstone and bioturbated (shoreface facies) beds to compare the palynological signals of the two facies. Rock samples were processed using standard $\mathrm{HCl}$ and $\mathrm{HF}$ palynological processing techniques. Samples were sieved using a 10 or 15 $\mu \mathrm{m}$ mesh sieve; initial samples were sieved at $10 \mu \mathrm{m}$, however no sporomorphs were recorded at $<20 \mu \mathrm{m}$ thus it was deemed adequate to sieve further samples at $15 \mu \mathrm{m}$. A minimum of 200 terrestrial sporomorphs were counted from each sample; taxa that were present in slides but not in counts were recorded as ' $p$ ' in the raw data. Botryococcus spp. was counted in addition to sporomorphs; each occurrence of Botryococcus spp. was counted as ' 1 ' in the raw data. Due to poor preservation in the majority of samples, most bisaccate pollen 
grains were grouped together. Quadraeculina anellaeformis and Vitreisporites pallidus were however distinguished from other bisaccates due to their distinctive characters. Vitreisporites pallidus is distinct from the majority of bisaccate pollen in that it probably originates from Caytoniales plants.

\subsection{Palynofacies analysis}

Previous palynofacies studies have provided useful information for the recognition of architectural elements within turbidites in general (e.g. McArthur et al., 2016a), and for the regional and large-scale stratigraphic and palaeoenvironmental interpretation of the Brent Group (e.g. Parry et al., 1981; Williams, 1992; Whitaker et al., 1992; Batten and Stead, 2005; Sawyer and Keegan, 1996). Here we use palynofacies analysis to provide more focussed interpretations based on targeted sampling of individual beds deposited under different depositional processes. The scheme of Williams (1992) is used here with some modifications and the following categories are applied: Amorphous Organic Matter (AOM), Blackwood, Brownwood, Plant cuticle, Dinoflagellate cysts (Dinocysts), Microforaminiferal test linings (Forams), Fresh/ brackish-water algae (e.g. Botryococcus spp.), Leiospheres, Non-saccate Pollen, Saccate Pollen, Megaspores, Spores, Tasmanites, Acritarchs, and Translucent phytodebris. Non-saccate and saccate pollen have been separated to assess more subtle patterns in pollen abundances between samples. 'Translucent phytodebris' refers to particles that are almost transparent to pale yellow in colour but which cannot be assigned to any other category. Such particles probably represent a mixture of broken marine and terrestrial palynomorphs and leaf cuticle fragments, however a more detailed classification is hampered by poor preservation. For extensive discussions of palynofacies analysis and palynofacies categories, see Tyson (1995) and Batten and Stead (2005). Counts of 500 particles were conducted under transmitted light; the size cut-off for particles was $15 \mu \mathrm{m}$.

\subsection{Data analysis}

Non-metric multidimensional scaling (NMDS) was used to assess compositional variation between samples. This is a non-parametric ordination method that uses ranked distances to assess the degree of similarity between samples. Samples that are compositionally similar plot close together and samples that are dissimilar plot far apart. The BrayCurtis dissimilarity metric was used here as this is considered to perform well in ecological studies (e.g. Harrington, 2008). Repeated runs were undertaken until a convergent solution was reached. NMDS was carried out using PAST (Hammer et al., 2001). For all NMDS plots, taxa that were present in samples but not in counts and singletons (taxa present in only one sample) were excluded from the data to reduce statistical noise. For the abundance matrix, taxon abundances were converted to relative abundances (percentages), so that the count total equals 100 for all sporomorphs in a given sample. For the presence-absence matrix, taxa that were present were scored as ' 1 ' and taxa that were absent were scored as ' 0 '.

To assess broad changes in vegetation through time, sporomorphs have been grouped according to their botanical affinity (Fig. 4). Botanical affinities are well constrained for many, but far from all taxa based on spore/pollen in situ (e.g. van Konijnenburg-van Cittert, 1978), wallultrastructure and grain morphological studies (e.g. Slater et al., 2015).

To assess changes in diversity, raw and rarefied species richness values are displayed for each sample (Fig. 4). Raw values refer to the number of species in the slide, i.e., including taxa that are present in slides but not in counts. Rarefied values are based on counts of 201 grains. Rarefaction calculations were carried out in PAST (Hammer et al., 2001).

In all analyses, relative abundances of Botryococcus spp. were calculated as a percentage of the total number of sporomorphs plus Botryococcus spp., and sporomorphs were calculated as 'standard' relative abundances; i.e. percentage values, relative to the total number of sporomorphs counted. Therefore, abundance shifts in Botryococcus spp. are recorded, but do not influence sporomorph abundance shifts.

\section{Results}

The studied wells have been correlated based on lithology, gamma ray, neutron and density logs (Fig. 4). Spore/pollen assemblages are dominated by typical Jurassic elements (e.g. Deltoidospora minor, Classopollis spp. and Perinopollenites elatoides) with 42 spore and 17 pollen taxa. Palynofacies counts are typically dominated by AOM, Blackwood and Brownwood with relatively small quantities of other components (Fig. 5). For raw sporomorph and palynofacies count data, see Supplementary Tables $1-2$ and for relative abundance sporomorph and palynofacies charts, see Supplementary Figs. 1-8.

\subsection{Well $211 / 13 A-8$}

\subsubsection{Palynology}

Fifteen samples were analysed spanning the interval 3646-3636 m from the lower part of the Rannoch Formation (Fig. 4). From these, 10 samples represent bioturbated sandstone intervals and five derive from structureless mudstones. All samples were productive with variable levels of preservation; palynofloras were accompanied by generally abundant fresh/brackish-water algae and scarce marine palynomorphs. Raw and rarefied species richness values for each sample (Fig. 4) are relatively consistent through time. Fig. 4 reveals few 'long-term' abundance and richness shifts in plant groups and individual taxa, suggesting that the vegetation was relatively static during the studied interval.

Perinopollenites elatoides overwhelmingly dominates together with Classopollis spp. Bisaccate pollen and Deltoidospora minor are also abundant. Simple monosulcate pollen grains (e.g. Cycadopites spp. and Chasmatosporites spp.) occur consistently within this and all other wells but in low relative abundances. Vitreisporites pallidus is generally more abundant in well $211 / 13 \mathrm{~A}-8$ compared to other studied wells.

\subsubsection{Palynofacies and Botryococcus spp. abundances}

Black and Brownwood remains are dominant throughout the studied interval. Amorphous Organic Matter displays high relative abundances within structureless mudstones. Dinoflagellates are low in abundance throughout, but are more abundant in the lower part of the studied interval. Botryococcus spp. is common throughout the samples, varying in abundance between 6 and $81 \%$. The palynofacies composition of structureless mudstone and sandstone samples does not vary greatly in core $211 / 13 \mathrm{~A}-8$, for example Botryococcus spp. abundances do not correlate strongly with lithology in core 211/13A-8, whereas in other cores Botryococcus spp. is only abundant within structureless mudstones.

\subsection{Well $211 / 14-3 Z$}

\subsubsection{Palynology}

Six samples were taken spanning the interval 3755-3741 $\mathrm{m}$ from the Rannoch Formation (Fig. 4). Three samples are from bioturbated sandstone intervals and 3 are from structureless mudstones.

Classopollis spp. and Perinopollenites elatoides dominate the basal samples together with Deltoidospora minor and unidentified bisaccate pollen, which show relatively low abundances compared to other cores. Interestingly, the sample located at $\sim 3746.5 \mathrm{~m}$ depth (fourth sample from the lowermost sample) is dominated by Spheripollenites spp. (53\%), and in the topmost sample Deltoidospora minor dominates. Raw and rarefied richness values are relatively consistent throughout the studied interval. 


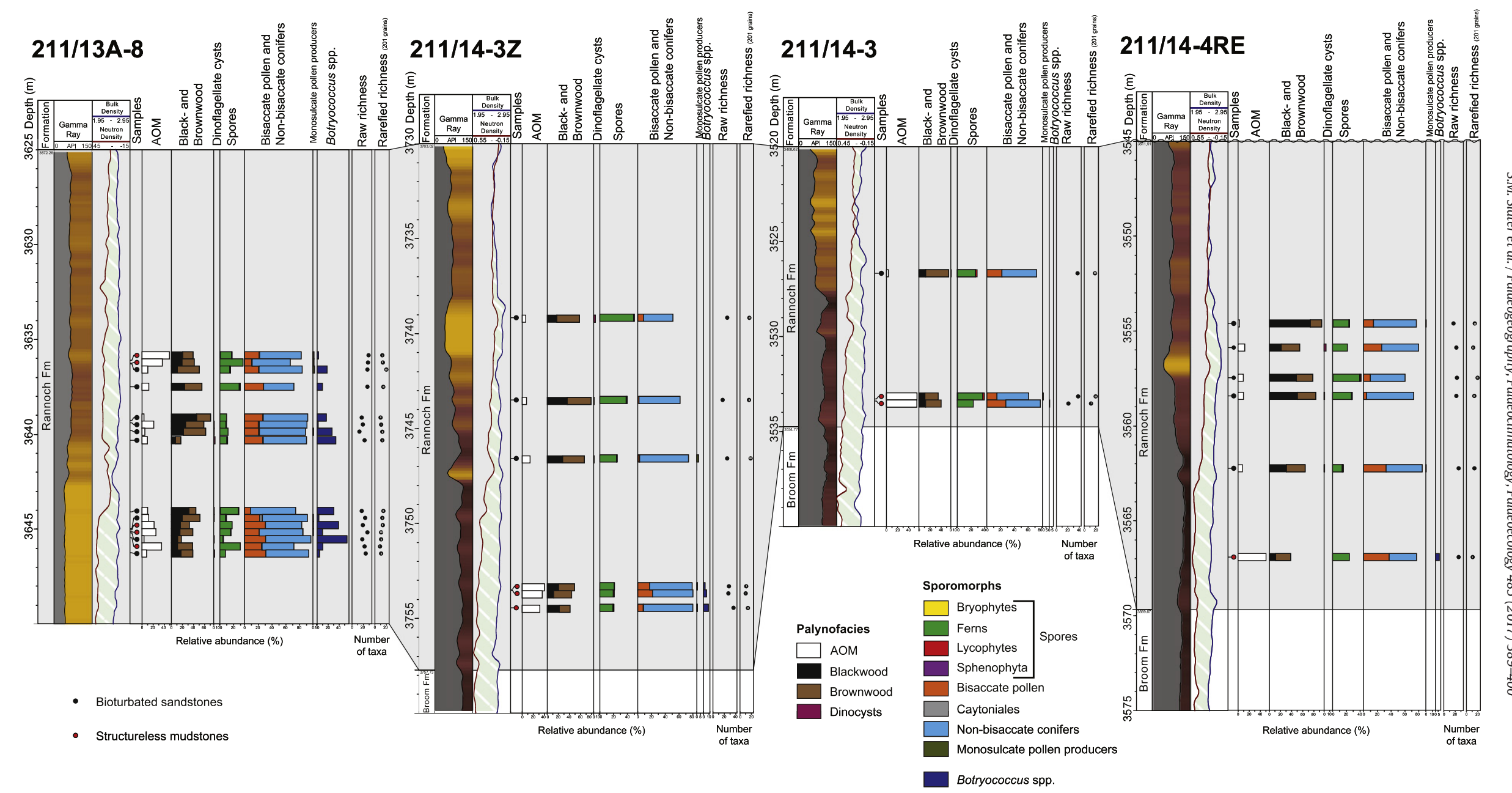

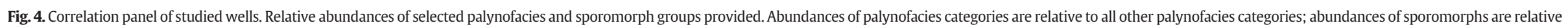

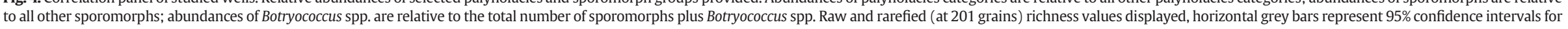
rarefied values. 
4.2.2. Palynofacies and Botryococcus spp. abundances

Black and Brownwood dominates within the studied samples. Dinoflagellates occur within sandstone beds and are moderately abundant within the uppermost sample. In the lower part of the section, within the structureless mudstones, AOM is abundant and correspondingly, Black and Brownwood remains record lower relative abundances. Botryococcus spp. is also more abundant within structureless mudstones in the lowermost three samples (Fig. 4).
Structureless mudstone samples
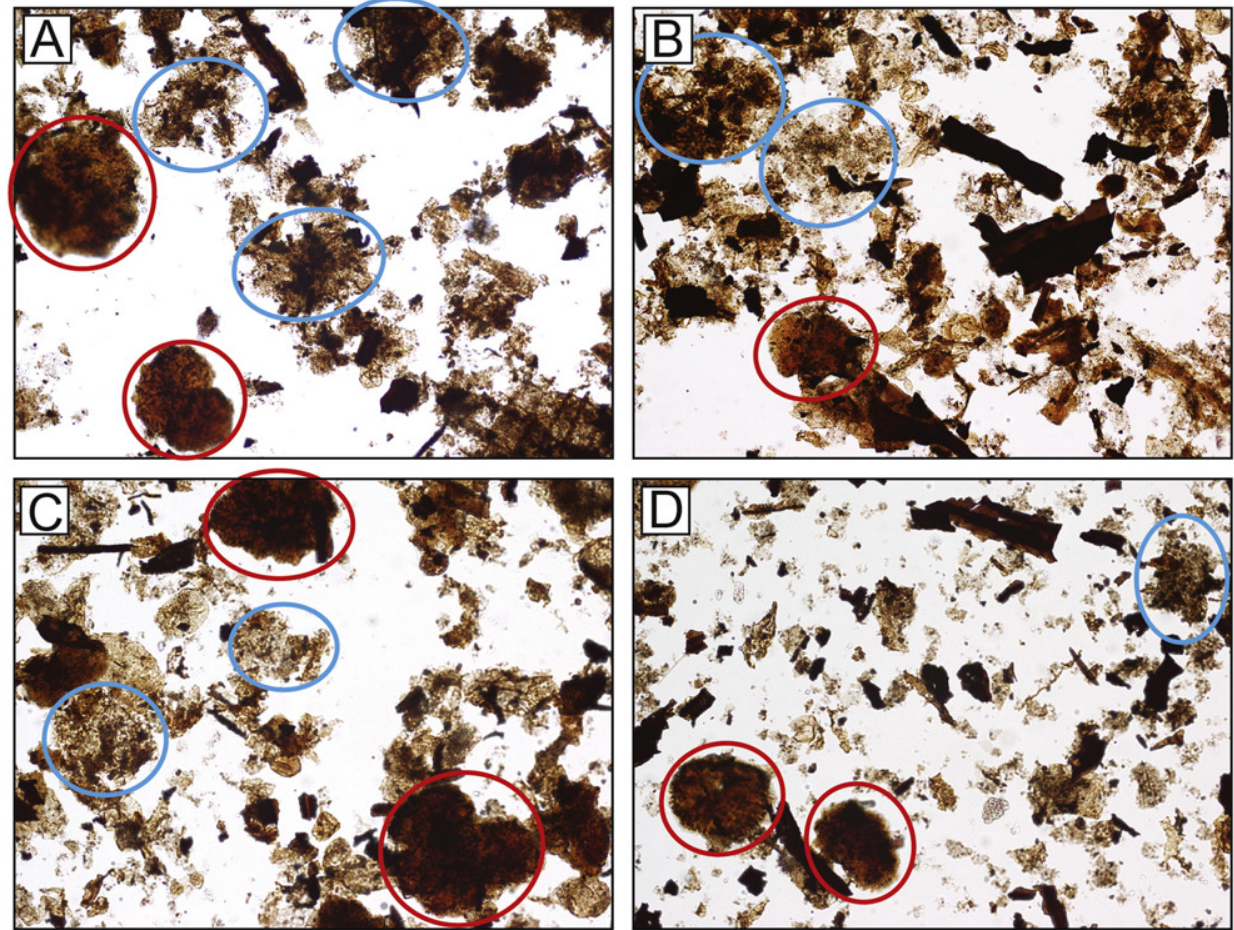

Bioturbated sandstone samples
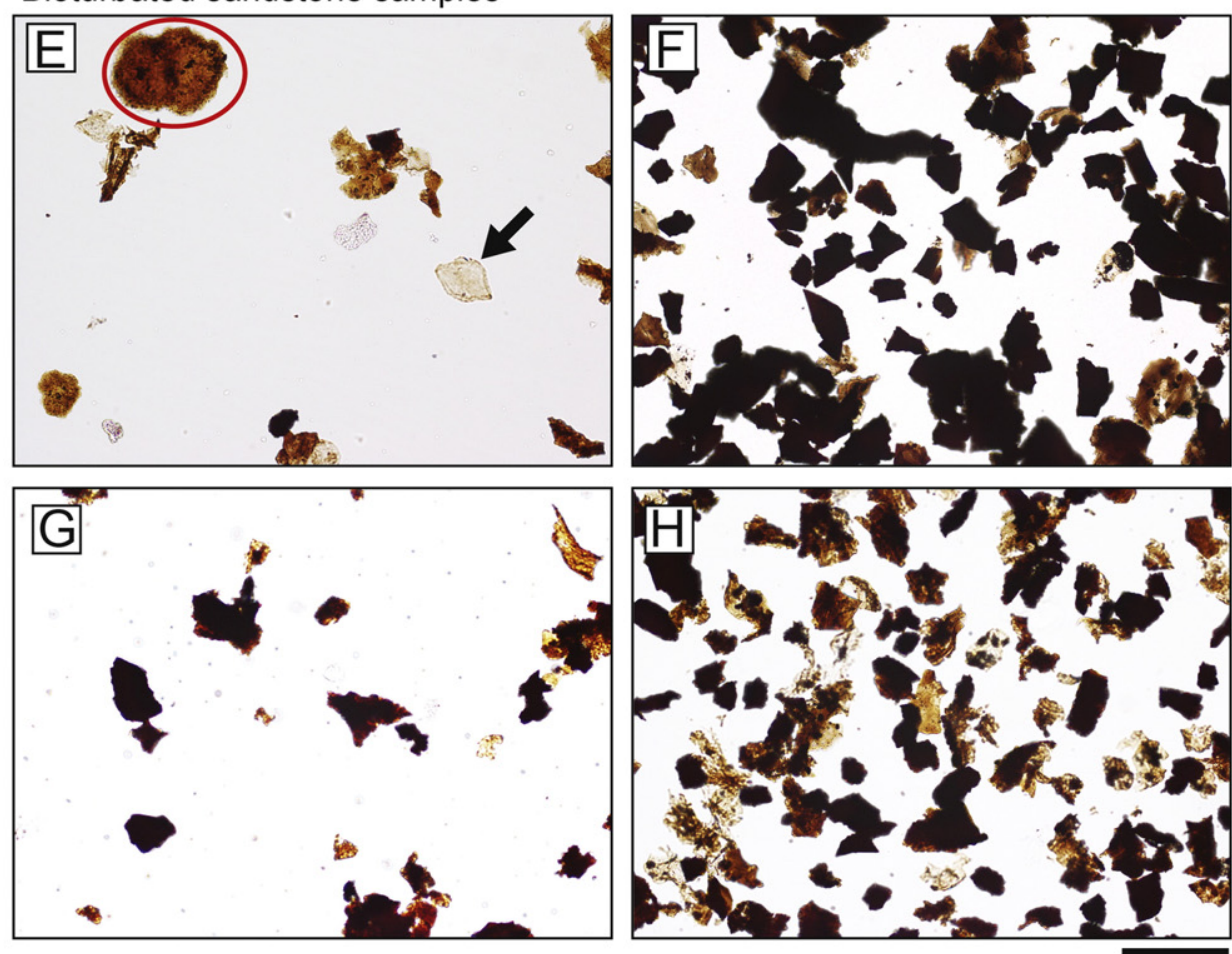

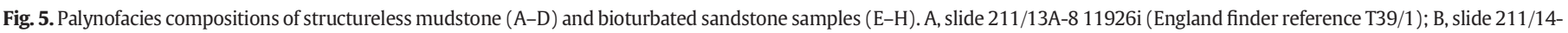

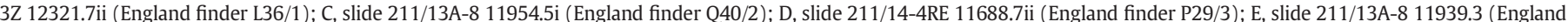

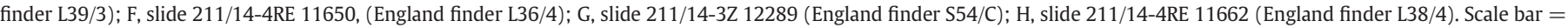

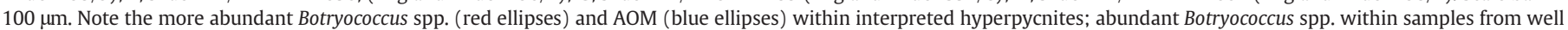
211/13A-8; and more abundant marine components within shoreface samples (e.g. arrow in E). 


\subsection{Well $211 / 14-3$}

\subsubsection{Palynology}

Three samples were taken spanning the interval $~ 3534-3526 \mathrm{~m}$ from the lower part of the Rannoch Formation (Fig. 4). From these, one sample was taken from a bioturbated sandstone interval and two samples were taken from structureless mudstones. The non-bisaccate group is dominant; of this Classopollis spp. is highly abundant in lower samples and Perinopollenites elatoides is highly abundant in the uppermost sample. Unidentified bisaccate pollen grains are abundant throughout (15-27\%) and Deltoidospora minor occurs at consistent levels among all samples (18-20\%). Raw and rarefied richness records display little change through time (Fig. 4).

\subsubsection{Palynofacies and Botryococcus spp. abundances}

Amorphous Organic Matter is highly abundant in the two structureless mudstone basal samples, reaching 38\%, whilst the uppermost sample is dominated by Brownwood. Dinoflagellates were only recorded in the uppermost sandier sample in low abundance. Botryococcus spp. is rare in all samples from core $211 / 14-3$, but the highest abundances are within the basal structureless mudstone sample.

\subsection{Well $211 / 14-4 R E$}

\subsubsection{Palynology}

Six samples were studied for palynology from the section spanning the interval 3567-3554 m from the Rannoch Formation. Five samples represent bioturbated sandstone intervals and one derives from a structureless mudstone.

Perinopollenites elatoides and Classopollis spp. dominate. Bisaccate pollen grains are highly abundant, particularly within the lowermost two samples. Similarly to other wells, spore abundances are dominated by Deltoidospora minor. Raw and rarefied richness values are relatively consistent through time (Fig. 4).

\subsubsection{Palynofacies and Botryococcus spp. abundances}

Black and Brownwood remains dominate in samples from the bioturbated sandstones, but in the lowermost sample (structureless mudstone), AOM is the most abundant palynofacies category. Blackwood is generally more abundant within samples from well 211/14-RE compared to other cores. Dinoflagellate cysts comprise a small portion of the total palynofacies count $(<1 \%)$, but are more abundant within bioturbated sandstone samples compared to structureless mudstones. Botryococcus spp. is only abundant in the lowermost structureless mudstone sample, reaching a relative abundance of $22 \%$ of the total palynomorph count.

\subsection{Sample ordination}

Ordination (NMDS) of samples using sporomorph relative abundance (percentage) data (Fig. 6A-D) demonstrates that samples from interpreted hyperpycnal and shoreface deposits cluster with limited overlap. This pattern is evident when Botryococcus spp. is excluded from the data (Fig. 6A), but is slightly more pronounced when this is included (Fig. 6B). This reflects the abundant Botryococcus spp. within
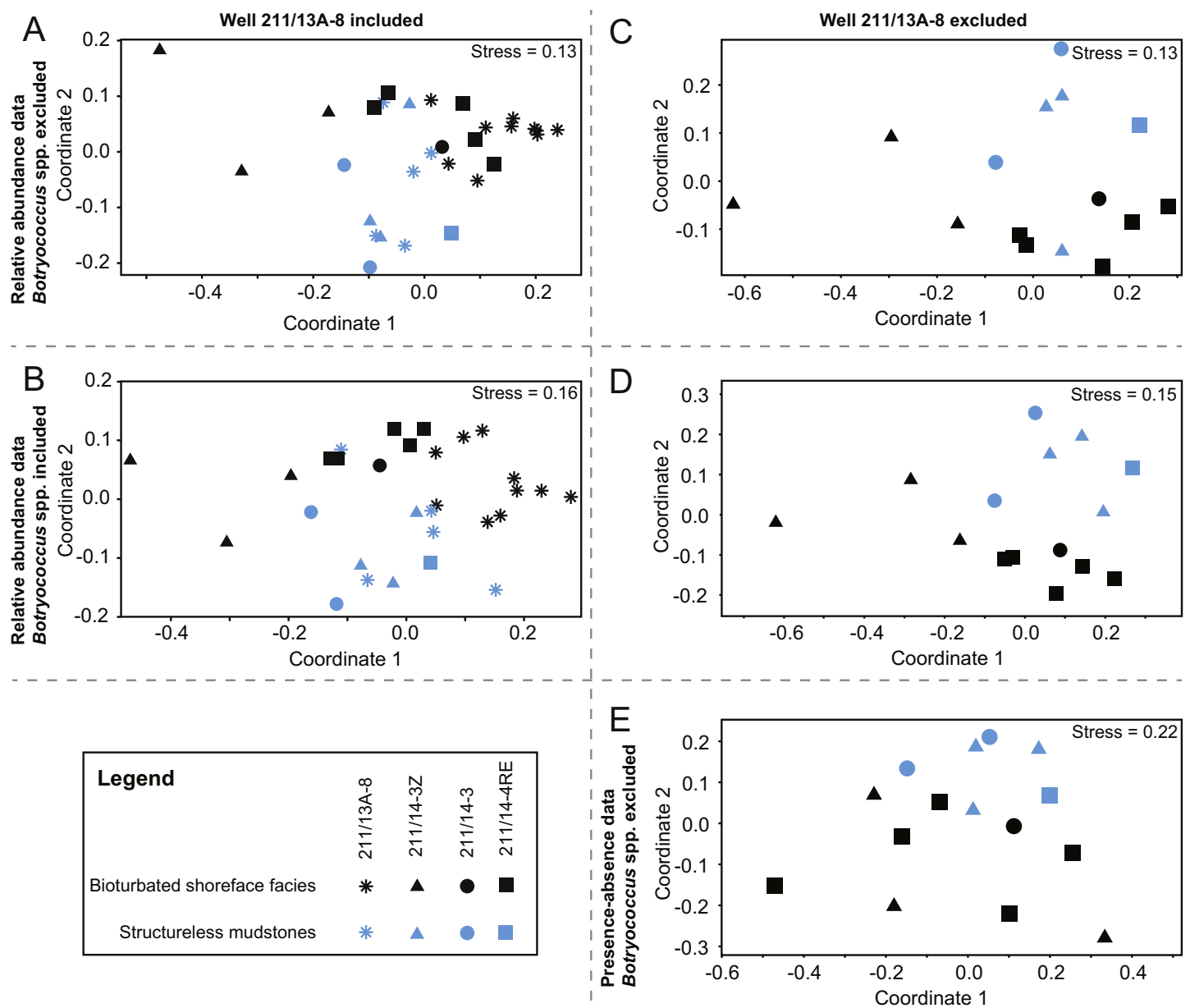

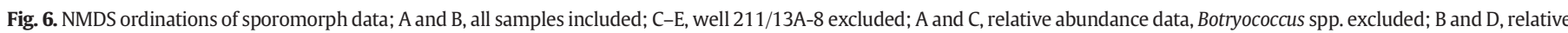
abundance data, Botryococcus spp. included; E, presence-absence data, Botryococcus spp. excluded. 
interpreted hyperpycnal deposits. Bioturbated shoreface samples cluster according to their well, demonstrating spatial variations in palynological assemblages between wells. Structureless mudstone samples are, however, highly similar regardless of their sampled well suggesting that depositional processes and spore/pollen sources (i.e. catchment zones) were similar among hyperpycnite deposit-forming flooding events of different wells. Ordination of samples using presence-absence data (Fig. 6E) also reveals that samples from structureless mudstones cluster relative to shoreface deposits. Structureless mudstone samples therefore display high compositional similarity, regardless of the geographical location of their sampled well. Limited clustering of wells is evident in presence-absence plots compared to relative abundance ordinations. This suggests that shifts in abundances of range through taxa are more important than the presence/absence of species among the different wells. When samples of well 211/13A-8 are excluded from the ordinations (Fig. 6C-E), interpreted hyperpycnites and shoreface deposits separate slightly more strongly. The northwards progradation direction of the Brent Delta (Richards, 1992; Went et al., 2013) would imply that well $211 / 13 \mathrm{~A}-8$ was located closer to a palaeoshoreline/ river mouth compared to other cores and the abundant Botryococcus spp. throughout this well, which originates from a non-marine source, supports this.

\section{Discussion}

\subsection{Comparison of structureless mudstones and bioturbated shoreface} facies

A general trend emerges when comparing the palynological and palynofacies assemblages of structureless mudstones and sandy successions; structureless mudstones are characterised by spikes in AOM and the fresh/brackish-water algae, Botryococcus spp. (Fig. 5) with generally higher abundances of Classopollis spp., bisaccate pollen and lower abundances of Perinopollenties elatoides. The structureless mudstones contain very low abundances of marine palynomorphs in palynofacies counts.

Correlation of cores using combined lithological, gamma ray, neutron and density data (Fig. 4), demonstrates that the sampled intervals are reasonably coeval and a lack of extensive temporal variation in sporomorph assemblages indicates that environmental change through time was limited. With the exception of core 211/13A-8, abundant Botryococcus spp. is confined to structureless mudstones. Abundant Botryococcus spp. throughout core $211 / 13 \mathrm{~A}-8$ is suggestive of a more persistent fresh water fluvial input in this well adjacent to the Penguins Cluster in comparison to the wells within the cluster (Fig. 4). Equally, rare Botryococcus spp. and common dinoflagellates (including Evansia spp., Kallosphaeridium spp., Mancodinium spp., Nannoceratopsis spp., $\mathrm{Pa}-$ reodinia spp. and Phallocysta spp.) within palynofacies counts of bioturbated sandy facies of cores 211/14-3, 211/14-3Z and 211/14-4RE suggests reduced fresh water input and more persistent shallow marine conditions. Spatial variations in Botryococcus spp. abundances are probably a result of the proximity of sampled environments relative to avulsive river mouths. Hence, the causes for variation in the distribution and abundances of Botryococcus spp. between wells appear linked to spatial variations in river mouth proximity. Marine components were not recorded in palynofacies counts from structureless mudstones, whereas marine components (mostly dinoflagellates) from sandier shoreface lithologies were common. The generally lower relative abundances of Black- and Brownwood remains within structureless mudstones are not considered to be an indicative feature of hyperpycnites here, as these lower relative abundances are due to higher abundances of AOM; when AOM is removed from the palynofacies raw data set prior to calculating relative abundances, Black- and Brownwood relative abundances are generally very similar or slightly higher within interpreted hyperpycnites compared to bioturbated shoreface facies. The terrestrial content of the structureless mudstones and paucity of marine components would appear to indicate that there was little turbulent mixing of hyperpycnal flows and fluid muds with ambient seawater or that a substantial freshwater wedge was present across these flows as they were depositing.

Within the interpreted hyperpycnites, abundant bisaccate pollen, much of which probably originates from hinterland conifers, in association with abundant Classopollis spp. suggests flood events that originated in upland drainage networks. These events also incorporated material from along the flood path to the coast from overbank flooding of lowland floodplains. Abundant Botryococcus spp. and AOM in structureless mudstones suggests a fresh/brackish-water setting with relatively low energy and low oxygen levels (e.g. relatively stagnant floodplain lakes or lagoons) (see Tyson, 1995; Roncaglia, 2004; Carvalho et al., 2006; Traverse, 2007; Pacton et al., 2011 for discussions regarding environmental reconstructions using AOM) for the environment from which these particles originated (i.e. prior to transportation), which would have been eroded during flooding events.

\subsection{Environmental reconstruction}

Sporomorph assemblages investigated here are highly similar to regional onshore Middle Jurassic deposits from Yorkshire and the East Midlands of the UK (Couper, 1958; Chaloner, 1968; Chaloner and Muir, 1968; Boulter and Windle, 1993; Hubbard and Boulter, 1997; Butler et al., 2005; Srivastava, 2011; Slater and Wellman, 2015; Slater and Wellman, 2016). Assemblages of the shoreface samples of the Rannoch Formation differ in generally possessing more abundant conifer pollen (e.g. Perinopollenites elatoides), which is expected within an offshore setting considering the hydrodynamic properties of conifer pollen (cf. Salter et al., 2002; McArthur et al., 2016a; cf. Stukins et al., 2017). The coniferous flora is dominated by Cupressaceae (Perinopollenites elatoides (van Konijnenburg-van Cittert and van der Burgh, 1989; Balme, 1995)) and Cheirolepidiaceae (Classopollis spp. (Balme, 1995)). Jurassic Cupressaceae trees are frequently interpreted to have inhabited swamp/poorly drained floodplain forests (e.g. Stukins et al., 2013), and Cheirolepidiaceae, a globally common extinct Jurassic gymnosperm, has been interpreted from a range of environments, including dry coastal (e.g. Hughes and Moody-Stuart, 1967; McArthur et al., 2016b) and upland settings (e.g. Filatoff, 1975). These trees comprised the canopy together with smaller portions of conifers producing Spheripollenites spp. and Callialasporites spp. Bisaccate pollen is highly abundant; several better preserved samples demonstrate that Alisporites spp. dominate the bisaccate pollen group. Alisporites spp. is similar to pollen recovered in situ from pteridosperm reproductive structures (e.g. Harris, 1964; Balme, 1995), thus a large portion of bisaccate grains here probably originate from pteridosperms. Such plants probably constituted the mid-storey vegetation. Low-storey vegetation comprised a combination of ground ferns and to a lesser degree, lycophytes (Fig. 7). Simple monosulcate pollen grains (e.g. Cycadopites spp. and Chasmatosporites spp.) occur consistently but in low relative abundances. Reconstructing parent vegetation with certainty based on these taxa is difficult due to their broad botanical affinities; Cycadopites spp. is known from the Cycadales, Ginkgoales, Peltaspermales and Bennettitales, and Chasmatosporites spp. is known from the Cycadales and Ginkgoales (Frederiksen, 1980; Balme, 1995). Cycad, Bennettitales and ginkgo macrofossils are common from coeval deposits from Yorkshire (e.g. Spicer and Hill, 1979), thus such pollen probably originates from several of these groups. Floras reconstructed here (Fig. 7) are dominated by typically warm-adapted groups (e.g. Cheirolepidiaceae); similar findings are recorded from palynological investigations of the Brent Group (e.g. Whitaker et al., 1992) and from the Jurassic of the central (e.g. McArthur et al., 2016b) and southern North Sea (e.g. Abbink, 1998; Abbink et al., 2001, 2004).

Hyperpycnite deposits concentrated within the lower part of the Rannoch Formation may have been a response to the developing climatic seasonality identified from coeval regional deposits of the Cleveland Basin, UK (Morgans et al., 1999). Such seasonality (possibly monsoonal) 


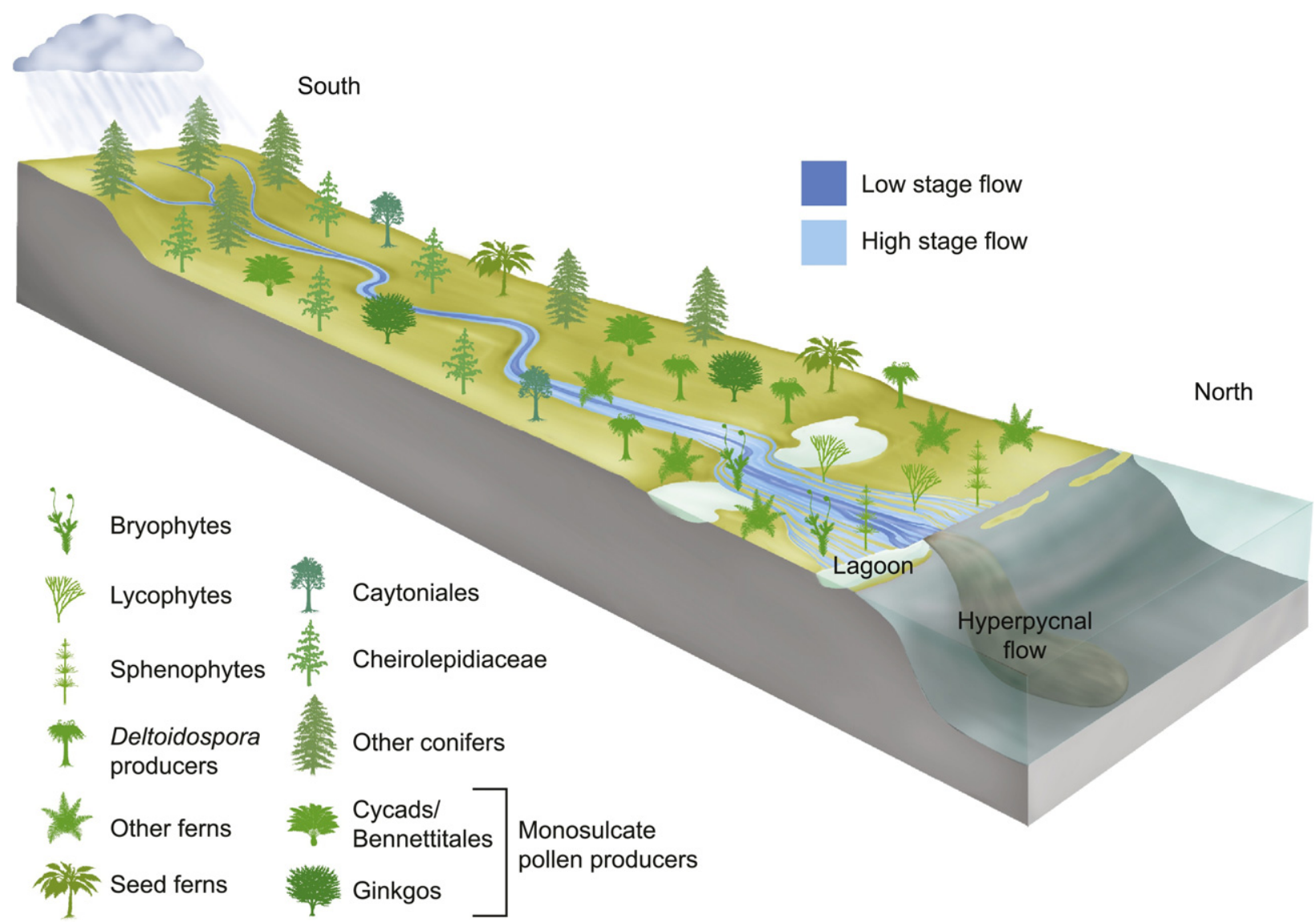

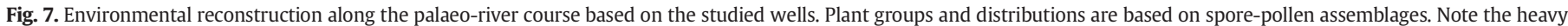

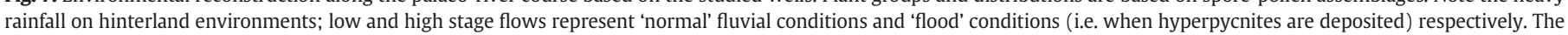
slope gradient from the terrestrial to marine environment is exaggerated to be steeper than reality.

and/or cyclic climatic changes may have resulted in more flood-prone discharge and higher suspended sediment concentrations conducive to hyperpycnal flows during wet seasons, together with a propensity towards limited fluvial supply and wave reworking during dry seasons. Extensive terrestrial floods with substantial suspended sediment concentrations may have been linked to the active rifting of the North Sea; short, steep sided drainage basins often present in active rift basins would presumably increase the likelihood of rapid floods (Mulder and Syvitski, 1995; Ichaso and Dalrymple, 2009).

\section{Conclusions}

Whilst the Brent Group has long been considered to be the product of large-scale deltaic progradation (Richards, 1992), and terrestrial palynomorphs are known to be abundant in the Rannoch Formation, this study has identified the bipartite nature of sedimentation within the Rannoch Formation, comprising wave reworked shoreface (with an open marine signature) and the former presence of river mouths recorded by flood deposits (with a terrestrial signature). Sediment supply was probably dominated by wet season flooding (possibly monsoonal) and dry season wave reworking of temporary mouth bar constructions. The flood deposits show preservation of terrestrial palynological assemblages within beds which are encased within a fully marine succession. Turbulent mixing with ambient seawater appears to have been minimal, particularly for the fluid mud deposits. The terrestrial assemblages encased in the hyperpycnites are characterised by abundant Botryococcus spp. which may indicate flood overspill of lakes and breaching of coastal lagoons. The conifer content is indicative of runoff from extrabasinal areas and direct transport to the coast. Palynology has proven to be a useful tool in identifying hyperpycnite deposits as terrestrial in origin, and provides an indication of the upland to lowland vegetation along the flood water path. The recognition of these processes on the Brent Delta improve our understanding of how the delta advanced at its northern limit as sediment supply became increasingly incapable of maintaining a progradational front across the Viking Graben.

Supplementary data to this article can be found online at http://dx. doi.org/10.1016/j.palaeo.2017.06.028.

\section{Acknowledgements}

This research was funded by a Natural Environment Research Council CASE (NE/J500100) Award with Shell Research Limited and a Swedish Research Council grant, VR 2015-04264. We thank Pollyanna von Knorring for artwork in Fig. 7. Finally, we thank four anonymous reviewers for their helpful comments and corrections.

\section{References}

Abbink, O.A., 1998. Palynological Investigations in the Jurassic of the North Sea Region. LPP Contributions. Utrecht University, Utrecht.

Abbink, O., Targarona, J., Brinkhuis, H., Visscher, H., 2001. Late Jurassic to earliest Cretaceous palaeoclimatic evolution of the southern North Sea. Glob. Planet. Chang. 30, 231-256.

Abbink, O.A., van Konijnenburg-van Cittert, J.H.A., van der Zwan, C.J., Visscher, H., 2004. A sporomorph ecogroup model for the Northwest European Jurassic - Lower Cretaceous I: concepts and framework. Neth. J. Geosci. 83, 17-38.

Balme, B.E., 1995. Fossil in situ spores and pollen grains: an annotated catalogue. Rev. Palaeobot. Palynol. 87, 81-323.

Bates, C.C., 1953. Rational theory of delta formation. Bull. Am. Assoc. Pet. Geol. 37 2119-2162.

Batten, D.J., Stead, D.T., 2005. Palynofacies analysis and its stratigraphic application. In: Koutsoukos, E.A.M. (Ed.), Applied Stratigraphy. Springer, Netherlands, pp. 203-226.

Bhattacharaya, J.P., Giosan, L., 2003. Wave-influenced deltas: geomorphological implications for facies reconstruction. Sedimentology 50, 187-210. 
Bhattacharaya, J.P., Maceachern, J.A., 2009. Hyperpycnal rivers and prodeltaic shelves in the Cretaceous seaway of North America. J. Sediment. Res. 79, 184-209.

Boulter, M., Windle, T., 1993. A reconstruction of some Middle Jurassic vegetation in northern Europe. Spec. Pap. Palaeontol. 49, 125-154.

Brown, S., Richards, P.C., 1989. Facies and development of the Middle Jurassic Brent Delta near the northern limit of its progradation, UK North Sea. In: Whateley, M.K.G., Pickering, K.T. (Eds.), Deltas: Sites and Traps for Fossil Fuels. Geological Society, London, Special Publications 41, pp. 253-267.

Budding, M.C., Inglin, H.E., 1981. A reservoir geological model for the Brent Sands in the Southern Cormorant. In: Illing, L.V., Hobson, G.D. (Eds.), Petroleum Geology of the Continental Shelf of the Northwest Europe. Heyden, London, pp. 326-334.

Butler, N., Charnock, M.A., Hager, K.O., Watkins, C.A., 2005. The Ravenscar Group: a coeval analogue for the Middle Jurassic reservoirs of the North Sea and offshore Mid-Norway. In: Powell, A.J., Riding, J.B. (Eds.), Recent Developments in Applied Biostratigraphy. The Micropaleontological Society Special Publications, London, pp. 43-53.

Cannon, S.J.C., Giles, M.R., Whitaker, M.F., Please, P.M., Martin, S.V., 1992. A regional reassessment of the Brent Group, UK sector, North Sea. In: Morton, A.C., Haszeldine, R.S Giles, M.R., Brown, S. (Eds.), Geology of the Brent Group. Geological Society, London, Special Publications 61, pp. 81-107.

Carvalho, M.D.A., Mendonça Filho, J.G., Menezes, T.R., 2006. Paleoenvironmental reconstruction based on palynofacies analysis of the Aptian-Albian succession of the Sergipe Basin, Northeastern Brazil. Mar. Micropaleontol. 59, 56-81.

Chaloner, W.G., 1968. The palaeoecology of fossil spores. In: Drake, E.T. (Ed.), Evolution and Environment. Yale University Press, pp. 125-138.

Chaloner, W.G., Muir, M., 1968. Spores and floras. In: Murchison, D., Westoll, T.S. (Eds.), Coal and Coal-Bearing Strata. Oliver and Boyd, Edinburgh and London, pp. 127-146.

Cheel, R.J., Leckie, D.A., 1993. Hummocky cross-stratification. In: Wright, V.P. (Ed.), Sedimentology Review 1. Blackwell Publications, Oxford, pp. 103-122.

Clifton, H.E., Thompson, J.K., 1978. Macaronichnus segregatis: a feeding structure of shallow marine polychaetes. J. Sediment. Petrol. 48, 1293-1302.

Couper, R.A., 1958. British Mesozoic microspores and pollen grains. Palaeontogr. Abt. B 103, 75-179.

Deegan, C.E., Scull, B.J., 1977. A standard lithostratigraphic nomenclature for the Central and Northern North Seas. Institute of Geological Sciences Report, 77/25; NPD-Bulletin No. 1.

Domínguez, J.S.M.L., 1996. The São Francisco strandplain: a paradigm for wave-dominated deltas. In: De Batist, M., Jacobs, P. (Eds.), Geology of Siliciclastic Shelf Seas. Geological Society, London, Special Publications 117, pp. 217-231.

Domínguez, R., 2007. Structural evolution of the Penguins Cluster, UK northern North Sea In: Jolley, S.J., Barr, D., Walsh, J.J., Knipe, R.J. (Eds.), Structurally Complex Reservoirs. Geological Society, London, Special Publications 292, pp. 25-48.

Duke, W.L., Arnott, R.W.C., Cheel, R.J., 1991. Shelf sandstones and hummocky cross-stratification: new insights on a stormy debate. Geology 19, 625-628.

Filatoff, J., 1975. Jurassic palynology of the Perth Basin, Western Australia. Palaeontogr. Abt. B 154, 1-113.

Frederiksen, N.O., 1980. Significance of monosulcate pollen abundance in Mesozoic sediments. Lethaia 13, 1-20.

Hammer, Ø., Harper, D.T., Ryan, P.D., 2001. PAST: paleontological statistics software package for education and data analysis. Palaeontol. Electron. 4, 1-9.

Hampson, G.J., Sixsmith, P.J., Johnson, H.D., 2004. A sedimentological approach to refining reservoir architecture in a mature hydrocarbon province: the Brent Province, UK North Sea. Mar. Pet. Geol. 21, 457-484.

Harrington, G.J., 2008. Comparisons between Palaeocene-Eocene paratropical swamp and marginal marine pollen floras from Alabama and Mississippi, USA. Palaeontology 51, 611-622.

Harris, T.M., 1964. The Yorkshire Jurassic flora II. Caytoniales, Cycadales and Pteridosperms. British Museum (Natural History), London.

Hayes, M.O., 1980. General morphology and sediment transport patterns in tidal inlets. Mar. Geol. 26, 139-156.

Hubbard, R.N.L.B., Boulter, M.C., 1997. Mid Mesozoic floras and climates. Palaeontology $40,43-70$.

Hughes, N.F., Moody-Stuart, J.D., 1967. Palynological facies and correlation in the English Wealden. Rev. Palaeobot. Palynol. 1, 259-268.

Ichaso, A.A., Dalrymple, R.W., 2009. Tide- and wave-generated fluid mud deposits in the Tilje Formation (Jurassic), offshore Norway. Geology 37, 539-542.

Jackson, C.A.L., Grunhagen, H., Howell, J.A., Larsen, A.L., Andersson, A., Boen, F., Groth, A. 2010. 3D seismic imaging of lower delta-plain beach ridges: lower Brent Group, northern North Sea. J. Geol. Soc. Lond. 167, 1225-1236.

van Konijnenburg-van Cittert, J.H.A., 1978. Osmundaceous spores in situ from the Jurassic of Yorkshire, England. Rev. Palaeobot. Palynol. 26, 125-141.

van Konijnenburg-van Cittert, J.H.A., van der Burgh, J., 1989. The flora from the Kimmeridgian (Upper Jurassic) of Culgower, Sutherland, Scotland. Rev. Palaeobot. Palynol. 61, 1-51.

Livera, S.E., 1989. Facies associations and sand-body geometries in the Ness Formation of the Brent Group, Brent Field. In: Whateley, M.K.G., Pickering, K.T. (Eds.), Deltas: Sites and Traps for Fossil Fuels. Geological Society, London, Special Publications 41, pp. 269-286.

Macquaker, J.H.S., Bentley, S.J., Bohacs, K.M., 2010. Wave-enhanced sediment-gravity flows and mud dispersal across continental shelves: reappraising sediment transport processes operating in ancient mudstone successions. Geology 38, 947-950.

McArthur, A.D., Kneller, B.C., Wakefield, M.I., Souza, P.A., Kulche, J., 2016a. Palynofacies classification of the depositional elements of confined turbidite systems: examples from the Gres d'Annot, SE France. Mar. Pet. Geol. 77, 1254-1273.

McArthur, A.D., Jolley, D.W., Hartley, A.J., Archer, S.G., Lawrence, H.G., 2016b. Palaeoecology of syn-rift topography: a Late Jurassic footwall island on the Josephine Ridge, Central Graben, North Sea. Palaeogeogr. Palaeoclimatol. Palaeoecol. 459, 63-75.
Mitchener, B.C., Lawrence, D.A., Partington, M.A., Bowman, M.B.J., Gluyas, J., 1992. Brent Group: sequence stratigraphy and regional implications. In: Morton, A.C., Haszeldine, R.S., Giles, M.R., Brown, S. (Eds.), Geology of the Brent Group. Geological Society, London, Special Publications 61, pp. 45-80.

Mjøs, R., 2009. Anatomy of the seaward steps and seaward termination of the Brent clastic wedge. Basin Res. 21, 573-596.

Morgans, H.S., Hesselbo, S.P., Spicer, R.A., 1999. The seasonal climate of the Early-Middle Jurassic, Cleveland Basin, England. Palaios 14, 261-272.

Mulder, T., Syvitski, J.P.M., 1995. Turbidity currents generated at river mouths during exceptional discharges to the world oceans. J. Geol. 103, 285-299.

Mulder, T., Migeon, S., Savoye, B., Faugères, J.-C., 2001. Inversely graded turbidite sequences in the deep Mediterranean. A record of deposits from flood-generated turbidity currents? Geo-Mar. Lett. 21, 86-93.

Mulder, T., Syvitski, J.P.M., Migeon, S., Faugeres, J.-C., Savoye, B., 2003. Marine hyperpycnal flows: initiation, behaviour and related deposits. A review. Mar. Pet. Geol. 20, 861-882.

Myrow, P.M., Fischer, W., Goodge, J.W., 2002. Wave-modified turbidites: combined-flow shoreline and shelf deposits, Cambrian, Antarctica. J. Sediment. Res. 72, 641-656.

Oertel, G.F., 1972. Sediment transport of estuary entrance shoals and the formation of swash platforms. J. Sediment. Res. 42, 857-863.

Olsen, T.R., Steel, R.J., 2000. The significance of the Etive Formation in the development of the Brent system: distinction of normal and forced regressions. In: Hunt, D. Gawthorpe, R.L. (Eds.), Sedimentary Responses to Forced Regressions. Geological Society, London, Special Publications 172, pp. 91-112.

Pacton, M., Gorin, G.E., Vasconcelos, C., 2011. Amorphous organic matter - experimental data on formation and the role of microbes. Rev. Palaeobot. Palynol. 166, 253-267.

Parry, C.C., Whitley, P.K.J., Simpson, R.D.H., 1981. Integration of palynological and sedimentological methods in facies analysis of the Brent Formation. In: Illings, L.V., Hobson, G.D. (Eds.), Petroleum Geology of the Continental Shelf of North-west Europe. Institute of Petroleum, London, pp. 205-215.

Pemberton, S.G., MacEachern, J.A., Gingras, M.K., Saunders, T.D.A., 2008. Biogenic chaos: Cryptobioturbation and the work of sedimentologically friendly organisms. Palaeogeogr. Palaeoclimatol. Palaeoecol. 270, 273-279.

Richards, P.C., 1992. An introduction to the Brent Group: a literature review. In: Morton, A.C., Haszeldine, R.S., Giles, M.R., Brown, S. (Eds.), Geology of the Brent Group. Geological Society, London, Special Publications 61, pp. 15-26.

Richards, P.C., Brown, S., 1986. Shoreface storm deposits in the Rannoch Formation (Middle Jurassic), North West Hutton oilfield. Scott. J. Geol. 22, 67-375.

Richards, P.C., Lott, G.K., Johnson, H., Knox, R.W.O'B., Riding, J.B., 1993. Jurassic of the central and northern North Sea (part 3). In: Knox, R.W.O'B., Cordey, W.G. (Eds.), Lithostratigraphic Nomenclature of the UK North Sea. British Geological Survey, Nottingham, UK, pp. 1-252.

Roncaglia, L., 2004. Palynofacies analysis and organic-walled dinoflagellate cysts as indicators of palaeo-hydrographic changes: an example from Holocene sediments in Skálafjord, Faroe Islands. Mar. Micropaleontol. 50, 21-42.

Salter, J., Murray, B.G., Braggins, J.E., 2002. Wettable and unsinkable: the hydrodynamics of saccate pollen grains in relation to the pollination mechanism in the two New Zealand species of Prumnopitys Phil. (Podocarpaceae). Ann. Bot. 89, $133-144$.

Sawyer, M.J., Keegan, J.B., 1996. Use of palynofacies characterization in sand-dominated sequences, Brent Group, Ninan Field, UK North Sea. Pet. Geosci. 2, 287-297.

Scott, E., 1992. The palaeoenvironments and dynamics of the Rannoch-Etive nearshore and coastal succession, Brent Group, northern North Sea. In: Morton, A.C., Haszeldine, R.S., Giles, M.R., Brown, S. (Eds.), Geology of the Brent Group. Geological Society, London, Special Publications 61, pp. 129-147.

Slater, S.M., Wellman, C.H., 2015. A quantitative comparison of dispersed spore/pollen and plant megafossil assemblages from a Middle Jurassic plant bed from Yorkshire, UK. Paleobiology 41, 640-660.

Slater, S.M., Wellman, C.H., 2016. Middle Jurassic vegetation dynamics based on quantitative analysis of spore/pollen assemblages from the Ravenscar group, North Yorkshire, UK. Palaeontology 59, 305-328.

Slater, S.M., Taylor, W.A., Batten, D.J., Hill, C.R., Wellman, C.H., 2015. Morphology and wall ultrastructure of a new and highly distinctive megaspore from the Middle Jurassic of Yorkshire, UK. Rev. Palaeobot. Palynol. 216, 33-43.

Southard, J.B., Lambie, J.M., Federico, D.C., Pile, H.T., Weidman, C.R., 1990. Experiments on bed configurations in fine sands under bidirectional purely oscillatory flow, and the origin of hummocky cross-stratification. J. Sediment. Res. 60, 1-17.

Spicer, R.A., Hill, C.R., 1979. Principal components and correspondence analyses of quantitative data from a Jurassic plant bed. Rev. Palaeobot. Palynol. 28, 273-299.

Srivastava, S.K., 2011. Spore-pollen biostratigraphy of the English Jurassic. Palaeontogr. Abt. B 285, 113-201.

Stukins, S., Jolley, D.W., Mcllroy, D., Hartley, A.J., 2013. Middle Jurassic vegetation dynamics from allochthonous palynological assemblages: an example from a marginal marine depositional setting; Lajas Formation, Neuquén Basin. Argentina. Palaeogeogr. Palaeoclimatol. Palaeoecol. 392, 117-127.

Stukins, S., Mcllroy, D., Jolley, D.W., 2017. Refining palaeoenvironmental analysis using integrated quantitative granulometry and palynology. Pet. Geosci. http://dx.doi.org/10. 1144/petgeo2016-073.

Sumner, E.J., Amy, L.A., Talling, P.J., 2008. Deposit structure and processes of sand deposition from decelerating sediment suspensions. J. Sediment. Res. 78, 529-547.

Traverse, A., 2007. Paleopalynology. second edition. Springer, Netherlands.

Traykovski, P., Geyer, W.R., Irish, J.D., Lynch, J.F., 2000. The role of wave-induced densitydriven fluid mud flows for cross-shelf transport on the Eel River continental shelf. Cont. Shelf Res. 20, 2113-2140.

Tyson, R.V., 1995. Sedimentary Organic Matter: Organic Facies and Palynofacies. Chapman \& Hall, London. 
Wei, X., Steel, R.J., Ravnås, R., Jiang, Z., Olariu, C., Li, Z., 2016. Variability of tidal signals in the Brent Delta front: new observations on the Rannoch Formation, northern North Sea. Sediment. Geol. 335, 166-179.

Went, D.J., Hamilton, R.V., Platt, N.H., Underhill, J.R., 2013. Role of forced regression in controlling Brent Group reservoir architecture and prospectivity in the northern North Sea. Pet. Geosci. 19, 307-328.

Whitaker, M.F., Giles, M.R., Cannon, S.J.C., 1992. Palynological review of the Brent Group, UK sector, North Sea. In: Morton, A.C., Haszeldine, R.S., Giles, M.R., Brown, S. (Eds.), Geology of the Brent Group. Geological Society, London, Special Publications 61, pp. 169-202.
Williams, G., 1992. Palynology as a palaeoenvironmental indicator in the Brent Group, northern North Sea. In: Morton, A.C., Haszeldine, R.S., Giles, M.R., Brown, S. (Eds.), Geology of the Brent Group. Geological Society, London, Special Publications 61 pp. 203-212.

Zavala, C., Arcuri, M., Di Meglio, M., Gamero Diaz, H., Contreras, C., 2011. A genetic facies tract for the analysis of sustained hyperpycnal flow deposits. In: Slatt, R.M., Zavala, C. (Eds.), Sediment Transfer From Shelf to Deep Water-Revisiting the Delivery System. AAPG Studies in Geology 61, pp. 31-51.

Zavala, C., Arcuri, M., Valiente, L.B., 2012. The importance of plant remains as diagnostic criteria for the recognition of ancient hyperpycnites. Rev. Paléobiol. 11, 457-469. 